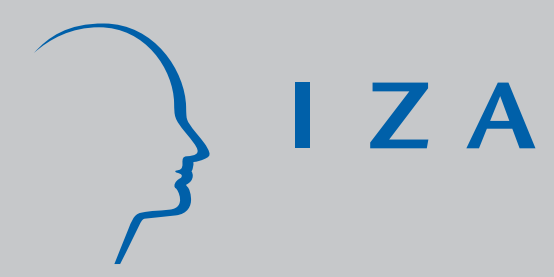

IZA DP No. 3248

Sweden's Pensioners: How They Have Fared in the Roller Coaster Ride through the Past Decade and a Half of Deep Recession and Economic Exuberance

Björn Gustafsson

Mats J ohansson

Edward Palmer

December 2007 


\title{
Sweden's Pensioners: How They Have Fared in the Roller Coaster Ride through the Past Decade and a Half of Deep Recession and Economic Exuberance
}

\author{
Björn Gustafsson \\ University of Göteborg \\ and IZA \\ Mats Johansson \\ Swedish Social Insurance Agency \\ Edward Palmer \\ Uppsala University \\ and Swedish Social Insurance Agency
}

Discussion Paper No. 3248
December 2007

IZA

P.O. Box 7240

53072 Bonn

Germany

Phone: +49-228-3894-0

Fax: +49-228-3894-180

E-mail: iza@iza.org

Any opinions expressed here are those of the author(s) and not those of the institute. Research disseminated by IZA may include views on policy, but the institute itself takes no institutional policy positions.

The Institute for the Study of Labor (IZA) in Bonn is a local and virtual international research center and a place of communication between science, politics and business. IZA is an independent nonprofit company supported by Deutsche Post World Net. The center is associated with the University of Bonn and offers a stimulating research environment through its research networks, research support, and visitors and doctoral programs. IZA engages in (i) original and internationally competitive research in all fields of labor economics, (ii) development of policy concepts, and (iii) dissemination of research results and concepts to the interested public.

IZA Discussion Papers often represent preliminary work and are circulated to encourage discussion. Citation of such a paper should account for its provisional character. A revised version may be available directly from the author. 


\section{ABSTRACT}

\section{Sweden's Pensioners: How They Have Fared in the Roller Coaster Ride through the Past Decade and a Half of Deep Recession and Economic Exuberance}

This study analyses the development of the economic well-being of the elderly in Sweden since 1990 - a period characterized by increased influence from the financial market and extreme economic events - using data from the Household Income Survey. The elderly were not isolated as pensions were cut, full indexation abandoned and taxes increased during Sweden's deep recession in the 1990s. Instead, relatively, pensioners fared better than the working age population. On the other hand, poverty increased in absolute terms. In contrast in the following years of rapid economic growth, the growth in the income of the pensioners fell behind that of workers and relative poverty increased. The analysis shows that the limited resources of many of the elderly put them close to a socially interesting poverty line. Income inequality among the elderly has increased with an increase in the importance of capital income for the better off among the elderly, with a clear tendency towards delineation between the better and worse off, which we conclude has implications for public expenditures for the elderly. Overall, poverty among the elderly in Sweden remains low in an international perspective and our analysis leads us to conclude that the Swedish welfare state has maintained its resilience.

JEL Classification: D31, H55, I32, J14

Keywords: Sweden, pensions, income, poverty, income inequality

Corresponding author:

Bjorn Gustafsson

Department of Social Work

University of Göteborg

P.O. Box 720

SE 40530 Göteborg

Sweden

E-mail: Bjorn.Gustafsson@socwork.gu.se 


\section{Introduction}

The income of the elderly in Sweden has increased continuously since 1960 as the universal earnings-related public pension scheme has matured, with occupational supplements developing into the mid-1970s for around 90 percent of employees, and with the continuous increase in female participation in the labor force. Women born in the 1940s and later have participated and earned pension rights to almost the same extent as

their male counterparts. By 1990, the standard of persons 65-74 was well over 90 percent of that of persons under 65 (Gustafsson and Palmer 1997).

The economic basis for this success story was hit hard in the beginning of the 1990s, when the slowdown in the world economy affected Sweden much more severely than most OECD countries. From 1990, open unemployment and benefits for the unemployed skyrocketed, with open unemployment going from under 4 in the beginning of 1990 to 14 percent in 1993 and with many more workers covered by labour market measures. Real GDP fell by 5 percent from 1990 to 1994. Taxes were increased and public transfer payments and outlays for public services were trimmed in an effort to limit mounting deficits. Among the transfers that were trimmed were benefit payments to pensioners. After practically five years of deep recession, the economy finally turned up in 1995. Since then Sweden has experienced substantial growth, albeit interrupted by the ruptured stock market bubble in 2001-2002. 
In this paper we investigate how the economic well-being of the elderly in Sweden defined as persons at least 65 years of age - changed during both the recession of the 1990s and ensuing period of prosperity. This we do by studying household disposable income using repeated cross sectional data covering the period 1991-2004, with historical reference points from 1975 and 1980. Our data source is the Household Income Survey compiled by Statistics Sweden from 1975.

Our study addresses the following questions: What has the turbulent period with deep recession, strong expansion and then a stock market crash meant for the income standard of the elderly relative to the total population? How has income inequality among the elderly developed and what happened to poverty among the elderly? Finally, what have the roles of pensions, capital and other income and taxes been throughout this turbulent decade and a half? Finally, we examine recent trends in a historical perspective, from 1975.

Sweden is often included in international comparative studies on income and income inequality. In these Sweden is typically among countries with the lowest incidence of low income of the elderly. One relatively early example is Atkinson et al. (1995) who, using data from the Luxembourg Income Study (LIS), show percentages of persons over age 60 with low incomes in Sweden and 13 other OECD countries in1981 and 1987. More recently, Förster and Pellizzari (2000) report that only 3 percent of persons above age 65 in Sweden fell under a poverty line of 50 percent of the median for equivalent disposable income in 1995. These authors also report summary-measures of income inequality 
indicating very low income inequality among the elderly in Sweden. The Gini-coefficient of 19.6 percent for the retired population in Sweden was the lowest reported for 19 countries. More recent figures from the LIS database also point in the direction of poverty (relatively defined) among the elderly in Sweden is smaller than in many, but not all other countries studied. ${ }^{1}$ Also, in a recent comparison of poverty rates among the elderly in the EU, Zaidi et al (2006) report that in Sweden in 200314 percent of people over 65 were under 60 percent of median income. ${ }^{2}$

In the Swedish literature Ruist (2002) examines the income situation for persons born in 1920 and concludes that the average income of the elderly was less affected by the business cycle than the average income of other groups. ${ }^{3}$ Vogel (2002, based on Vogel et al. 2000) uses a much broader definition of well-being than ours, investigating changes in living and health conditions among the young, middle-aged and elderly for the period $1980-1998 .{ }^{4}$ A conclusion of this work is that the living and health conditions of the elderly improved, whereas those for the young became worse.

Whereas Gustafsson and Palmer (1997) examine the period 1975-1990 in detail, none of the more recent studies analyse the development of the income status of the elderly during the entire period of turbulence from 1990. This paper's contribution is to analyse

\footnotetext{
${ }^{1}$ http://www.lisproject.org/keyfigures.htm

${ }^{2}$ Among the EU 25 Lithuania, the Slovak Republic, Hungary, the Netherlands, Luxembourg, Poland and the Czech Republic were found to have lower relative poverty rates among the elderly.

${ }^{3}$ Our analysis differs from Ruist's. He examines only mean income for a single cohort, using personal gross income, rather than household disposable income, an income concept more closely related to well-being, with an analysis of covering only the first half of the 1990s.

${ }^{4}$ Statistics Sweden (2006) carries this analysis forward to cover the entire period 1980 to 2003. Although covering many aspects those studies does not study income inequality among the elderly and what has made it change.
} 
in depth how one of the world's leading welfare states coped with a long period of economic crisis and managed the following recovery vis-à-vis the elderly. The study also provides interesting insights into the roles of various income components in determining the income status of old age pensioners in a modern welfare state.

The rest of this paper is organised as follows: In the next section we describe changes in policy during the period examined that affected the elderly. Section 3 describes the data used in our study. Section 4 examines the trend in the development of the average income of the elderly while we take a closer look at the distribution of income among the elderly in Section 5. The issue of poverty and low income among the elderly is penetrated in Section 6, while Section 7 addresses the question of what is behind the development of inequality of income inequality among the elderly. We sum up the main conclusions in Section 8. 


\section{The changing scene}

Most of the elderly in Sweden live in small households, either with a spouse or alone. Multigenerational households are rare. Until recently, following the new pension reform and the legislation of the right to work until 67, it has been unusual for others than the self-employed and a handful of professionals over 65 to be employed and earn wages. Instead, the income of persons 65 and older consists mainly of pensions of which the major component is a public pension, although earnings are still a source of income for some up to around the age of 70. As has already been mentioned, most employees will also have earned rights to an occupational supplement to their public pension. During the past decade and a half, capital income has also become increasingly important as a source of income. Finally, in addition to being the main provider of pensions, the public sector also provides means tested housing benefits, which constitute soft means-tested income support for the low income elderly. In addition, the elderly are required to pay income taxes.

Until 2001, public pensions for the elderly consisted of a flat rate benefit based only on years of residence and an earnings-related pension, which for a person with a typical work history constituted the main benefit. People without an earnings-related pension received a supplement to their flat-rate benefit. A new pension system has been phased in since 2001. ${ }^{5}$ Both prior to 2001 and after, when a guarantee benefit level replaced the flat rate, low-income pensioners have been entitled to housing benefits. Women born before

\footnotetext{
5 The Swedish pension reform is explained in more detail in e.g., Palmer (2000) and Könberg, Palmer and Sundén (2006).
} 
1945 can receive a widow's pension. There was an extra tax deduction for pensioners until 2001, which meant that pensioners with low pensions were exempted from income taxes. With the reform in 2001, all pension income is taxed using the same rules as those that apply for wage earners. At the same time, the guarantee has been set so as to be neutral vis-à-vis the pre-reform tax deduction, so as to create a neutral transition into the new regime.

Benefit levels are related to the consumer price index. Benefit amounts are stated as multiples of a "base amount", which is indexed with inflation. While originally straightforward, the relation between the development of the consumer price index and the base amount became increasingly blurred in the 1990s as policy makers attempted to cut back on expenditures during the recession. ${ }^{6}$ Over the period 1991 to 1998, the increase in indexation was about 10 percent lower than it would have been if it had been adjusted to the increase in the consumer price index. In addition the basic pension was decreased by 2 percent in 1993, a change that remained to 1998. These changes meant that the real value of pensions gradually fell from 1991 until 1998. From 2001, with the introduction of the new reform, benefits have been indexed upwards with the growth rate of real per capita covered earnings minus $1.6 \%$. This indexation was positive during 2001-2004, the years covered by this study. This indexation occurs in addition to indexation for price inflation.

\footnotetext{
${ }^{6}$ A first step was taken in 1991 and 1992 when the increase of the base amount was reduced by 2.93 respectively 3.19 percent with the motivation of a large tax reform lessening the income tax burden of the elderly. Problematic public finances were stated as reasons for reducing the increase of the base amount 1994 by 1.9 percent. This was followed by the innovation of including the size of the public sector budget benefit into the formula for calculating the updating of the base amount. As a consequence the increase in the base amount in 1995 was reduced by 1.05 percent, and the corresponding numbers for 1996, 1997 and 1998 were, respectively, 1.05 percent, 0.19 percent and 0.09 percent. See Ministry of Social Affairs (2002).
} 
Generally, pensions of new pensioners are higher than those of previous pensioners as rights have grown with the increase in real earnings of workers. Also, the proportion of the elderly (mainly women) receiving only basic (guarantee) pensions has become small in the past decade and a half as female pensioners with longer working careers have "replaced” female pensioners without or with only limited working careers. Also, policy focused on the poorest during the recession, as pension supplements to people with no earnings-related pension were higher in 1993 than in 1990. In addition, due to the need to consolidate the public sector budget, income taxes were increased at the highest end of the income distribution, which could affect even the most well-off pensioners. Consolidating the financing of the public sector also meant fewer resources for public services. Since the elderly more frequently use health care services and of course care for the elderly, such cuts certainly must have had welfare consequences for the elderly. However, these changes are not shown in our study as it focuses on household disposable income.

While it is true that the economic situation of the elderly in Sweden was influenced in many ways by the public sector and the necessity of curb a rapidly increasing imbalance between revenues and expenditures, there were other factors at work changing the economic situation of the elderly. Many, though far from all, elderly persons traditionally have savings and an increasing proportion of the elderly were stockholders during the 1990s. The 1990s was a period with high interest rates and a buoyant stock market, which benefited net savers. On the other hand, the first years of the new century saw also a 
dramatic fall in stock prices, with a market recovery that took until 2004. In sum, all of the factors discussed here were at work during the period examined in this study. 


\section{Measuring the income of the elderly}

For this study we use data from the Swedish Household Income Survey (HINK/HEK) compiled by Statistics Sweden. This annual survey has existed since the middle of the 1970s, and typically comprises between 10000 and 19000 households. Our study focuses on the period 1991 to 2004, but we also use data from 1975 and 1980 to compare the development and outcome in the 1990s with the preceding decade. There is a methodological problem that arises in comparing the years before 1991 with those from 1991 on, because the tax base was broadened in 1991. This definitional change led to an increase in household factor income of about 5 percent $^{7}$ and is the reason why we begin this study with 1991.

HINK covers people in private households. Those living in institutions such as homes for the elderly are not covered. When analysing the period here under study using annual data we have to work with a definition of the household which allows for up to two adults and children aged up to 18 . This means that multi-generational households are treated as separate units in most of the analyses presented here. ${ }^{8}$ Information on earnings, pensions, other transfers and income taxes is obtained from public registers, and is supplemented with information obtained with telephone interviews.

\footnotetext{
${ }^{7}$ There are also other changes in methodology over the years; Sample size has changed for example. Most likely they are of little importance for the results. HINK/HEK is also available in the Luxembourg Income Study (LIS), but not for all years used here. Pay attention to the fact the definition of income used in Luxembourg Income Study is harmonized across countries meaning that some components available in the data we work with are not included.

${ }^{8}$ Since 1995 (and for 1991) HINK/HEK also has a broader definition of household thereby allowing household to have more than two persons over 18 years of age. When we report on relative poverty, and this for the sake of comparability with previously published (half-official) numbers of poverty, we shift to a
} 
The main unit of measurement in this study is equivalent disposable income. Equivalent disposable income is obtained by dividing disposable income by an equivalence scale, which follows social assistance norms (as formulated during the 1980s) including housing costs. (See Gustafsson 1987 for a detailed description of the procedure used). "Norm" housing costs are based on the size of the household and the region of the country where people reside. Individuals constitute the unit of analysis in the study. We assume consumption opportunities are equally shared within the household, which means that all household members share the household income. An equivalent income value of 1.0 means that the income of members of the household, considered separately, is exactly equivalent to the social assistance norm for a single person living in the same region of the country.

In this way, we obtain values for all persons aged 65 and older, compute the average for various years, compare average income of the elderly to the average for all people in the population and analyse inequality in income among the elderly. Our approach also makes it possible to study income poverty among the elderly. 


\section{The development of average income among the elderly}

The real standard of living of persons 65 and older in Sweden has increased steadily for several decades. In 1975 the average equivalent disposable income of all persons 65 and older was only about twenty percent above the social assistance norm (Gustafsson and Palmer, 1997). Three decades later, in 2004, the average equivalent disposable income of persons 65 and older was a little over twice the social assistance norm (Table 1a). As Table 1a shows, since the early 1990s, young pensioners (65-74 years) have on average, about the same economic standard as the rest of the population while the average equivalent income of older pensioners is lower.

/Table 1 about here/

Sweden has experienced three recessions since the late 1970s. The first began in the late 1970s and continued into the early 1980s, the second began in1991 and lasted through 1994 and the third began in 2002 and culminated around 2005. Figure 1 shows a clear tendency for growth of the average income of the elderly to stagnate during these recessions. What are the reasons for this?

The first two recessions were characterized by the development of substantial government budget and current account deficits and ensuing pressure on the Swedish krona, both times leading to substantial devaluations. Pensions, which in principle are priced indexed, were not indexed to compensate for the effect of the devaluations on the 
price index. As we have discussed in the preceding section, other adjustments were also made in the recession of the 1990s and, as a result, the indexation of benefits was about 10 percent less during 1991-1998 than would have been motivated by true price adjustment, as we have discussed above. There was no index adjustment accompanying the 2002 recession however.

As Table 1a shows the average income of persons 65 and older decreased by 3 percent during severest of Sweden’s recession years, in 1991-1995. Real average income would have decreased by more had it not been for the continuous inflow of new pensioners with pensions based on higher earnings than their predecessors and the continuous outflow of the oldest pensioners with the lowest pensions. Most importantly, however, the average income of the entire Swedish population fell by 13 percent from 1991 to 1995 (Table 1a). Generally, although pensions were not fully indexed during the recession, as a group pensioners nevertheless fared better than the rest of the population. Surprisingly, persons 75 and older fared slightly better than persons aged 65 - 74 (See Table 1a). Since pensions of all pensioners were indexed with the same index, the relative strength of this group also attests to the natural turnover in the "stock" of older pensioners from less to more well-off pensioners, the long-term trend alluded to in the preceding section.

Spikes also stand out, in 1994 and 1999 in Figure 1. These are years in which large holdings of equities were cashed in, leading to capital gains. This attests to the increasing importance of financial portfolios in the welfare of older households. Also, a factor 
contributing to the 1999 spike was the increase in the benefit levels to compensate for the absence of full indexation during the recession of the early 1990s.

/Figure 1 about there/

Table 1b shows that while the average income of the elderly was 86 percent of the average for the entire population at the beginning of the recession in 1991, by 1996, the turning point of the recession, it was as high as 98 percent, which was more an indication of the relative drop in the income of wage earners than of gains of pensioners. This ratio has remained high since then, at a level around 90 percent during the later years of study. What's more Table 1b shows that on average pensioner households have caught up with households with children. The average income of households with persons 65 and older relative to households with children was 94 percent in 1991, in the beginning of the recession, and 111 percent at the end in 1996. In 2004, the latest measurement year for this study, the income per person of these two groups was essentially the same, signalling a clear gain for pensioners on families with children since $1990 .^{9}$ The fall in the relative position of pensioners from 1996 through 2001 reflects the general tendency for the relative income of persons with price-adjusted fixed incomes to fall relative to working households with real income gains in periods of economic prosperity.

In sum, the 1990s was a decade in which pensioners gained considerable turf relative to the rest of the population. The gain was strong during the recessionary years of the first

\footnotetext{
${ }^{9}$ In addition, pensioner households are generally much better off than single parent households, although this is nothing new. The gap has increased since household income statistics were first compiled in 1975.
} 
half of the decade. However, in the ensuing expansion they lost some of this ground. Nevertheless, in 2004 the standard of persons 65 and older relative to other groups was somewhat higher than in the early 1990's. In fact, the standard of persons 65 and older was on a par with Swedish society's other target group for social policy, households with children.

\section{A closer look at the distribution of income among the elderly}

The previous section concluded that as a group and during most (but not all) years, the elderly fared better than the rest of the population. This is not the whole story, however, as is shown by an examination of the distribution of income among persons 65 and older. To see this we examine the development of inequality among the elderly.

/Table 2 about here /

/ Figures 2a and 2b about here /

Table 2 reports the equivalent disposable income for the elderly by quintile since 1991 . This is complemented with Figures 2a and 2b, which shows the development of quintiles, for people aged 65 - 74 and $75^{+}$, respectively. Table 2 shows that the income of persons in the first quintile is generally close to the social assistance norm. The average real income of persons in this quintile decreased during the recession and was only about four percent over the norm at its lowest point in 1998. The average real income of persons in 
the second, third and fourth quintiles also fell and remained lower during and immediately after the recession. The two first quintiles did not reach their pre-recession levels until 2001, while for quintiles three and four this took place two years earlier. Turning to the highest quintile, the development of the average is much more irregular. This reflects the importance of earnings and capital income for this group, which we will return to below. What dominates the picture, however, is that the average income of the fifth quintile increased more or less continuously during the entire period.

Figures $2 \mathrm{a}$ and $2 \mathrm{~b}$ reveal more clearly how the averages disguise a dramatic change in the distribution of real income among pensioners since the end of the recession of the 1990s. Quintiles for persons 65-74 show that the distribution remained stable throughout the worst years of the recession but spread out right after the recession, from 1996, with per capita real income increasing faster in successively higher quintiles. The pattern is similar for quintiles for persons 75 and older but with relatively smaller gains in the decade following the recession, especially for persons in the lower quintiles.

/ Table 3 about here/

Table 3 reports the Gini-coefficient of disposable equivalent income for persons aged 65 to 74 and 75 and older. ${ }^{10}$ The Gini coefficient was on average 0.205 in the beginning of the 1990s (1991-1993) and 0.261 at the end of our data period (2002-2004) for the younger elderly. For persons 75 and older the (3-year average) Gini coefficient increased

\footnotetext{
${ }^{10}$ The Gini-coefficient is probably the most frequently used measure of income inequality. It assumes values from 0 (no income inequality) up to 1.
} 
from 0.171 to 0.224 in the same period. ${ }^{11}$ The development of the Gini coefficients confirm, then, the picture of increasing within-group inequality from the mid-1990s, revealing an underlying trend in increasing inequality among the elderly that has its roots in the pre-reform pension system. ${ }^{12}$ Also note that the change towards greater income inequality among the elderly is not isolated to this group but is an ongoing pattern observed for the general population and for a large range of subgroups (see Gustafsson and Palmer 2002).

In sum, for all but the fifth quintile, real per capita income fell at the outset of the recession and didn’t reach pre-recession levels until around a decade later, in 1999-2001. Generally, once real growth returned real per capita income improved progressively faster for higher quintiles. The major conclusion of this section is, then, that in the past decade, following the recession in the mid-1990s, inequality among pensioners has increased profoundly.

\footnotetext{
${ }^{11}$ We have also computed the Theil index and the MLD index. The results show that while the three indices do not always move in the same direction from one year to the next, they show the same pattern. Our results suggest that if Förster and Pellizzari (2000), whose study was based on data for 1995, would have had access to Swedish data for 1994 or any of the years 1996-1999, income inequality among the elderly in Sweden would not have been the very lowest. Still our results suggest that income inequality among the elderly in Sweden was probably lower than in many of the other countries investigated in their study.

${ }^{12}$ The first cohort covered by the new system consisted of those born 1938, most of whom claimed their pensions in 2003 at the age of 65. Even for them, however, the "new system" comprised $25 \%$ and the old system rules $75 \%$ of their benefits, due to a transition rule.
} 


\section{Poverty and low income among the elderly}

The results above show that the per capita real income of the elderly in the first quintile is only slightly above the social assistance norm as it was formulated in the 1980s. This is an average for the lower - fifth of the population, however, and it is important to study the distribution within this group to make any clear statement about poverty. There is no official poverty line in Sweden. In lieu of this, to study "poverty", two different approaches can and normally are used. One is to follow the procedure of the European Union and measure relative poverty (See Atkinson et al., 2002). The other is to construct some measure of absolute poverty. Two such measures are examined in this study. This examination will, in fact, show just how significant the choice of approach is.

First, following the approach used in most comparative research, the poverty line can be defined as a fraction of median or mean income of the entire population examined. In much comparative research the poverty line is set at 50 or 60 percent of the median of overall equivalent income. This is a relative measure. It means that the level of income in a country does not affect the poverty assessment, what matters is the shape of the distribution. If the shape of the distribution is more-or-less unchanged as the economy grows then the assessment of persons in poverty will remain largely unchanged over time. 
/Table 4 about here/

We have observed above that although disposable income for the first quintile of the elderly fell during the recession in the 1990’s, so did the average for the entire population, and even at a higher pace. Therefore we do not expect a relative measure to show an increase in relative poverty, rather it should show a decrease. This is also what can be extracted from Table 4. This table shows a drop in the proportion of elderly under 60 percent of the median from 17 percent in 1991 to only 7 percent in 1996, but thereafter changes tend to be in the direction of increases. At the end of the period under study the rate is back at the level recorded at the beginning of the period. The development of the proportion elderly under 50 respectively 70 percent of the contemporary median income is similar, although the levels are - not surprisingly - rather different. ${ }^{13}$

Since the relative measure of poverty follows the rate of growth both upwards and downwards it can be more suitable to apply a poverty line which is constant in purchasing power. With this sort of measure one can see how many fall below the poverty line in recession and "escape” poverty with growth. This is the approach taken when computing official estimates of poverty in the United States, for example. Following this approach we base the poverty line on the recommendations issued by the

\footnotetext{
${ }^{13}$ Our estimate of the proportion of the elderly under 50 percent in 1995 is close to the one reported by Förster and Pellizzari (2000) for the same year and level of the poverty line. Similarly our estimate of the proportion of the elderly under 60 percent of the median in 2003 is close to that reported for the same year and by Zaidi et al. (2006), as is the level of poverty. Our data show that the proportion falling under 40 percent or under 50 percent of median contemporary income is about the same for people aged $65-74$ and those 75 and older. However, for higher poverty lines there are clear differences, with the oldest much worse off. For example in 2003 while 6.7 percent of those 65 to 74 were under 60 percent of the median the corresponding proportion among those 75 and older was 19.3 percent.
} 
Swedish Board of Health and Social Welfare for scales used in processing social assistance applications (see Gustafsson 1987 for more details). This measure is based on a consumption basket, in the present context including regionally delineated costs for housing, and is indexed to the consumer price index. In addition, indexation was not tampered with during the recession, as was the case for the index actually used for adjusting pension benefits to prices.

/Table 5 about here/

/Figure 3 about here/

Table 5 and Figure 3 report the proportion of the elderly that fell under the social assistance norm each year, as well as the proportion that fell under 75 and 125 percent of this level. Only about a half to one percent was under 75 percent of the norm during the entire period under study, which indicates that poverty among the elderly is shallow.

Consistent with the findings reported in the previous section on falling equivalent disposable income, at the lowest end of the distribution, there is an increase in the proportion of persons 65 and older falling under the poverty line from the end of the recession in 1993, continuing through 1998 from 3.5 percent in 1993 to 7.7 percent in 1998. In 1998 the proportion under the poverty line reached its 1980 level (a year in the middle of the preceding recession). However, after extra indexation of benefits in 1999 and following a period with continuous growth only 2.9 percent of persons 65 and older 
were under the absolute poverty line in 2004. A slight increase in the poverty line to 125 percent yields a proportion close to 20 percent in poverty in the early 1990s increasing to about 26 percent in 1998 but then falling to a little more than 10 percent in 2004. This can be compared to a level of 33 percent in 1980. This confirms that near "absolute" poverty among the elderly in Sweden has declined considerably during the past quarter century.

Looking at age groups among the elderly reported in Table 5, the highest poverty rates are reported for the oldest. Persons over 75 are more likely than persons under 75 to have incomes that place them just over the poverty line; they are almost poor. Table 5 shows that the increase in the proportion of persons at or below the poverty lines of 100 and 125 percent increased through 1998 for both age groups, but beginning with a much greater number for those 75 and older. From a low of 8 percent in 1992, the proportion of persons aged 65 - 74 under 125 percent of the norm was 15 percent in 1998 and then fell to about six percent in 2004. Among those aged $75+$ the increase was from a low of 26 percent in 1993 up to 37 percent in 1998 followed by a decrease to 15 percent in 2004.

In sum, the data show that a relative measure of poverty yields fewer elderly in poverty during a recession. In addition, relative poverty among all persons 65 and older was similar in 2003 as it was in 1991. The proportion in poverty was not very different from that for the entire population. Within the period studied relative poverty among the decreased during the recession and then increased. This confirms that the income of the elderly has a much weaker link to the business cycle than the income of people in 
economically active ages. However, when we assess poverty in terms of a poverty line representing constant purchasing power, poverty among the elderly increased during the recession, reflecting benefit cuts and abandonment of full price indexation until 1999. As benefits and indexation returned to normal in 1999 poverty among the elderly decreased. In fact, it was at its lowest level in the past quarter century in 2004, for both the younger and the elder elderly. 


\section{What's behind the increase in inequality among the elderly?}

In this section we analyze the increase in inequality from the mid-1990s by examining the various components of disposable income and their contributions to changes in the Gini coefficient. The framework for the analysis is slightly different from that used in the previous sections, as the analysis is carried out for people living in households where the household head is 65 or older.

/Table 6 about here/

Table 6 reports the various income sources for the years 1975, 1991 and 2004 - their levels, their relative shares of equivalent disposable income (EDI) and their concentration coefficients. The concentration coefficient can assume values from - 1 which indicates a total concentration to those with the lowest EDI to +1 standing for total concentration to

persons with the highest EDI. ${ }^{14}$ The table also shows the contributions of each source of equivalent disposable income to total income inequality in a particular year. (See Rao, 1969 and Pyatt, Chen and Fei, 1989 for the methodology.)

According to Table 6, the Gini-coefficient for the population under study increased from 18.1 in 1975 to 21.4 in 1991 up to 25.9 in 2004 . Starting with earnings of men and women, we find that their shares of EDI decreased considerably between 1975 and 1991 in part due to the decrease in the general retirement age from 67 to 65 in July 1976. In 2004 earnings of both men and women comprised only about four percent of EDI. 
However, earnings are strongly concentrated to those with high EDI as indicated by the high and for men increasing concentration coefficient.

While earnings have thus become a rather small part of the total income package of the elderly in Sweden, the reverse is true for capital income which is in our definition made up of interest, dividends, imputed rents of owner occupied housing and capital gains. This component constituted 14 percent of EDI in 1975, 18 percent in 1991 and 20 percent in 2004. Not only has the relative share of capital income increased, but its concentration coefficient has doubled, to as much as 70 in 2004. As we will see below this is what is driving the strong increase in income inequality.

In Table 6 we distinguish between taxable transfers (primarily pensions) and untaxed transfers (primarily income tested housing benefits). Pensions have a positive concentration coefficient which means that people at the top of the distribution receive larger sums than those at the bottom. Not surprisingly the opposite is true for means tested transfers, indicating that transfers are well targeted towards those at the bottom of the income distribution. Looking at changes over time, the concentration coefficient for pensions was about the same at the beginning and end of the entire period examined, with a less dramatic increase in 1991. On the other hand the negative value for the concentration coefficient for the means tested transfers became larger throughout the period signifying that means tested transfers have been increasingly better targeted towards those at the bottom of the distribution. Also their relative shares in EDI have

\footnotetext{
${ }^{14}$ For the definition see for example Lambert (2001).
} 
moved in different directions. While pensions have increased their share, means tested transfers have decreased their share of EDI during the period studied.

Finally in Table 6 we can observe that the relative share of taxes increased between each pair of years studied. The tax rate (calculated as taxes in relation to gross income) increased from 21 percent in 1975 to 25 percent in 1991 up to 28 percent in 2004. The concentration coefficient decreased considerably throughout the period, suggesting taxes have become less redistributive.

/Figure 4 about here/

Based on this decomposition we are now ready to ask how different income sources have contributed to the increase in the Gini-coefficient. It is possible for each component to affect the development through a changed relative share as well as through a changed concentration coefficient. The development of the Gini-coefficient from 1991 to 2004 can be followed year by year. The decomposition gives numbers on concentration coefficients and relative shares for each component for every year under study compared to 1991.

According to Figure 4 the main cause of increased income inequality among the elderly is capital income. Its effect is strong throughout the entire period and despite considerable variation its effect is higher in 1999 than before. Capital income also lies behind the "spikes" throughout the period. 
The development of pensions contributed to the increase in inequality, especially between 1995 and 1999, but only slightly and then not at all thereafter. In fact in the final years examined pensions contributed to a decrease in inequality compared to 1991. This could be a result of the replacement of older female pensioners with low survivor pensions by younger female pensioners with their own earnings-related pensions. However, it could also be the effect of the introduction of the new pension system which entailed converting the pre-reform flat rate benefit with a separate deduction to a taxed guarantee benefit without a separate deduction, but with a gross adjustment in the benefit to compensate for the excluded tax deduction. This may also explain why taxes became less distributive during this period, too. Two forces, earnings and income taxes, counteracted the increase in income inequality throughout the entire period, first, increasingly so throughout 1999, then, less thereafter. In fact, from around 2001 capital is the single remaining strong driver of inequality. 


\section{Conclusions}

This paper focuses on the economic standard of the elderly in Sweden. The focus has been on the period from 1991 but throughout we have related this period to history covering the past 25-30 years. This has put the more recent developments into a longer historical perspective and enables us even to draw conclusions about the long-run trend. The study uses data from the household income survey for each year from 1991 until 2004, as well as data for 1975 and 1980.

On methodology, this study illustrates that it is important to go beyond an analysis focusing on the average income of the elderly and comparison of this with other groups in society. In addition, it is important to examine the development of income inequality among the elderly. Even if pensions are by far the most important income component other sources of income are important for examining differences in income within this large group. In the Swedish setting, both capital income and taxes turn out to be important.

This said, there is still more to do. For example, we have studied the younger and older elderly, but have not had access to information about persons living in institutions. We have worked with the consumer price index whereas for some groups of the elderly, especially the elder elderly it may be more relevant to construct a special index that takes

the typical consumption basket of this group into consideration. For example, the elderly are the largest consumers of publicly provided home help. Finally our analysis is of 
cross-sectional character. Much new and for policymakers relevant knowledge on the income of the elderly in Sweden can be obtained by using panel data. Such data has the potential for revealing patterns of change and stability at the individual level as well revealing events affecting changes in income. ${ }^{15}$

This study has several findings. First we found that the average status of the elderly has continued to improve in absolute terms, but this did not occur smoothly nor did it occur at the same pace as changes in the income of economically active persons. The average income of the elderly was much more stable during the deep recession and consequently their relative income position improved. However, the elderly were not isolated from the deep recession as pensions were cut, full indexation abandoned and taxes increased. In contrast, during the years of rapid economic growth, income of the country's seniors did not increase as fast as for others and their relative income position deteriorated.

Second, the achievement of the pensions and other parts of the Swedish welfare system in reducing poverty among the elderly during the 1970s and 1980s to a low level in an international perspective is still a salient feature of the welfare state in 2003 and 2004, the final years of our study. However, our results also show that many elderly have rather limited resources, placing them close to a poverty line. With decreased benefits during the first half of the 1990s, larger proportions of the elderly slipped under a poverty line based on fixed purchasing power. From 1998 the proportion has been decreasing. However, since then, real income among the working age population has tended to grow

\footnotetext{
${ }^{15}$ Some first steps in analysing income of the elderly in Sweden by panel data can be found in Statistics Sweden (2006) and in Zaidi and Gustafsson (2007).
} 
more rapidly than the income of the elderly, leading to an increase in after the recession in the proportion of the elderly below 60 percent median income. A conclusion is that that the problem of relative poverty among the elderly in Sweden has not been erased from the policy arena.

A third conclusion is that income inequality among the elderly in Sweden increased from the end of the recession in the 1990s and at an increasing rate. By 2004 the income of the fifth quintile had increased by 33 percent since 1991, while income of the first quintile was only 8 percent higher than in 1991. Just as has been the case for high-deciles "insiders" in the labor force, i.e., those fortunate enough to have work throughout the 1990s (Gustafsson and Palmer 2002), the well-being of well off pensioners was not affected by the recession, whereas the average income of the worst off declined and did not begin to increase again until the end of the decade.

A fourth conclusion is that there have been changes in the role played by various income sources for the economic situation of the elderly. Earnings have become insignificant as a source of income for all but earnings of men for the well off. Instead, the role of capital income has gradually increased. Capital income is increasingly concentrated to elderly persons with high incomes, and the development of capital income is the main reason why income inequality among the elderly increased from the mid-1990s. In addition pension income has tended to be more unequally distributed which can be traced to newer cohorts of retirees with higher earnings-related public and occupational pensions based on more recent real economic growth. Income taxes have counterbalanced the forces 
leading to greater income inequality among the elderly but to a lesser extent from the end of the 1990s.

Our findings have policy implications. They illustrate that the elderly in Sweden are economically much less of a homogenous category than they used to be. This has important implications in, for example, pricing of social services and determining the mix between private and public provision of services for the elderly. One part of the reality is that a substantial number of elderly have difficulties in making ends meet. They can not afford to pay much for social services and health care and can not actively demand private health care and services. Arguments for public provision and particularly public funding of services for those elderly remain therefore strong. On the other hand, there are also elderly who live in better economic conditions than most of the population and, if markets exist, can actively demand private health care and services. To formulate policies that take both those categories' interests in account is a challenge for policymakers. This is particularly so as universality in delivery in the Swedish environment is typically seen as having a value of its own. 


\section{References}

Atkinson, A.B., Rainwater, L. \& Smeeding, T. (1995) Income Distribution in OECD Countries, Paris: Organisation for Economic Co-operation and Development, Social Policy Studies No 18.

Atkinson, A., Cantilon, B., Marllier, E. \& Nolan, B. (2002) Social Indicators. The EU and Social Inclusion, Oxford: Oxford University Press.

Förster, M, Pellizzari, M. (2000) Trends and Driving Factors in Income Distribution and Poverty in the OECD Area, Paris: Organisation for Economic Co-operation and Development, Labour Market and Social Policy - Occasional Papers No 42.

Gustafsson, B. (1987) Ett decennium av stagnerande realinkomster (A Decade of Stagnating Real Income), Stockholm: Statistics Sweden (levnadsförhållanden Rapport 54).

Gustafsson, B. \& Palmer, E. (1997) "Changes in Swedish Inequality: A Study of Equivalent Income 1975 - 1991” in Gottschalk, P., Gustafsson, B., and Palmer, E. (eds.) Changing Pattern in the Distribution of Economic Welfare - an International Perspective, Cambridge: Cambridge University Press.

Gustafsson, B. \& Palmer, E. (2002) “Was the Burden of the Deep Swedish Recession Equally Shared?” Review of Income and Wealth, 48 (4) 537 - 560

Gustafsson, B., Zaidi, A. \& Franzén, E. (2007) “Financial Poverty (Chapter 3)” in International Journal of Social Welfare, Supplement 1 (Social Report 2006. The National Report on Social Conditions in Sweden, Edited by Danuta Biterman), 35 - 90.

Könberg, B., Palmer E. \& Sundén A. (2006) “The NDC Reform in Sweden: The 1994 Legislation to the Present” in R. Holzmann and E. Palmer (eds.) Pension Reform through NDCs: Issues and Prospects for Non-Financial Defined Contribution Schemes. World Bank: Washington DC.

Lambert, P. (2001) The Distribution and Redistribution of Income, 3d edition, Manchester: Manchester University Press

Ministry of Social Affairs (2002) Gyllene år med silverhår - för vissa eller för alla? Ett bokslut över pensionärernas situation under 1990-talet (Golden year with silver linings for some or for all? A balance sheet on the pensioner's situation during the 1990s) Stockholm: Ds 2002:14.

Pyatt, C., Chan, C.N. \& Fei, J. (1980) “The Distribution of Income by Factor Components” Quarterly Journal of Economics, 95, 451 - 73. 
Rao, V.M. (1969) “The Decomposition of the Concentration Coefficient” Journal of Royal Statistical Society, vol 132, 418 - 25.

Ruist, E. (2002) “Har pensionärerna fått det bättre?” (Are pensioners better off?) Ekonomisk Debatt, 30, (4) 335 - 342.

Statistics Sweden (2006) Äldres levnadsvilkor - Arbete, ekonomi, hälsa och sociala nätverk 1980 - 2003 (Living conditions of the edlerly, work, economy, health and social networks 1980 - 2003.) Living conditions report no 112, Stockholm

Vogel, J., Häll, L., Johansson, S. - E. \& Skjöld, C. (2000) Äldres levnadsförhållanden (Living conditions of the Elderly), Stockholm: Statistics Sweden, Series Levnadsförhållanden Rapport 93.

Vogel, J. (2002) “Ageing and Living Conditions of the Elderly: Sweden 1980 - 1998” Social Indicators Research, 59, 1 - 34.

Zaidi, A. \& Gustafsson, B. (2007) "Income Mobility among the Elderly in Sweden during the 1990s” International Journal of Social Welfare, 16, 84 - 93.

Zaidi, A., Makovec, M., Fuchs, M., Lipszyc, B., Leikes, O., Rummel, M., Marin, B. \& de Vos, K. (2006) Poverty of Elderly People in EU 25, Vienna, European Centre for Social Welfare Policy and Research. 
Table 1a. Mean Equivalent Disposable Income* for Old-age pensioners. Ratio to the Social Assistance norm with Housing Costs. 1980 and 1991-2004.

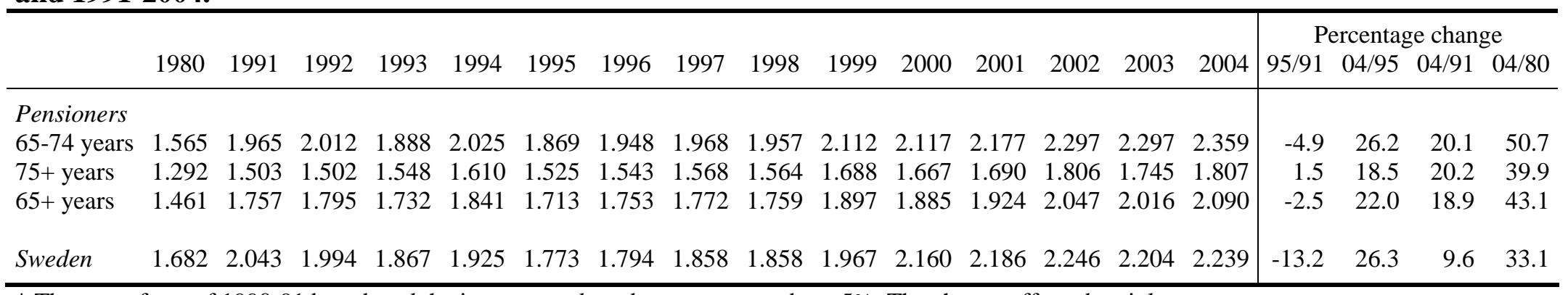

* The tax-reform of 1990-91 broadened the income-tax base by on average about $5 \%$. The change affected mainly persons in the higher deciles. For this reason measured income is not fully comparable before and after the reform.

Table 1b. Relative Income of Pensioners 65 Years and Older. 1980 and 1991-2004.

\begin{tabular}{|c|c|c|c|c|c|c|c|c|c|c|c|c|c|c|c|}
\hline & 1980 & 1991 & 1992 & 1993 & 1994 & 1995 & 1996 & 1997 & 1998 & 1999 & 2000 & 2001 & 2002 & 2003 & 2004 \\
\hline \multicolumn{16}{|l|}{$\begin{array}{l}\text { Relative Income of } \\
\text { pensioners to: }\end{array}$} \\
\hline All & 86.8 & 86.0 & 90.0 & 92.8 & 95.6 & 96.6 & 97.7 & 95.3 & 94.7 & 96.4 & 87.3 & 88.0 & 91.1 & 91.5 & 93.4 \\
\hline Families, 0 children & 74.6 & 76.3 & 80.3 & 83.8 & 86.2 & 87.9 & 87.4 & 85.7 & 86.3 & 88.6 & 79.9 & 78.9 & 83.5 & 83.7 & 85.4 \\
\hline Single parents & 104.2 & 117.9 & 115.0 & 123.0 & 135.4 & 131.0 & 131.7 & 138.9 & 132.5 & 137.2 & 127.5 & 127.9 & 132.5 & 137.8 & 141.2 \\
\hline
\end{tabular}


Table 2. Mean Equivalent Disposable Income for Old Age Pensioners in Quintiles. Ratio to the Social Assistance norm with Housing Costs. 1991-2004.

\begin{tabular}{cccccc}
\hline & Quintile 1 & Quintile 2 & Quintile 3 & Quintile 4 & Quintile 5 \\
\hline 1991 & 1.114 & 1.384 & 1.575 & 1.853 & 2.859 \\
1992 & 1.139 & 1.413 & 1.616 & 1.918 & 2.887 \\
1993 & 1.127 & 1.380 & 1.562 & 1.831 & 2.759 \\
1994 & 1.113 & 1.374 & 1.564 & 1.854 & 3.296 \\
1995 & 1.071 & 1.354 & 1.541 & 1.814 & 2.785 \\
1996 & 1.093 & 1.358 & 1.553 & 1.838 & 2.925 \\
1997 & 1.062 & 1.328 & 1.528 & 1.804 & 3.135 \\
1998 & 1.037 & 1.312 & 1.532 & 1.851 & 3.062 \\
1999 & 1.059 & 1.369 & 1.592 & 1.940 & 3.525 \\
2000 & 1.065 & 1.364 & 1.591 & 1.953 & 3.450 \\
2001 & 1.096 & 1.414 & 1.653 & 2.017 & 3.439 \\
2002 & 1.143 & 1.466 & 1.733 & 2.131 & 3.761 \\
2003 & 1.167 & 1.489 & 1.733 & 2.117 & 3.573 \\
2004 & 1.202 & 1.523 & 1.774 & 2.146 & 3.806 \\
\hline
\end{tabular}

Table 3. Gini-coefficient for Equivalent Disposable Income for Pensioners 65-74 Years and 75 Years and Older. 1991-2004.

\begin{tabular}{ccc}
\hline & 65-74 Years of Age & 75 Years and Older \\
\hline 1991 & 0.206 & 0.180 \\
1992 & 0.211 & 0.162 \\
1993 & 0.197 & 0.171 \\
1994 & 0.241 & 0.218 \\
1995 & 0.207 & 0.185 \\
1996 & 0.221 & 0.185 \\
1997 & 0.239 & 0.219 \\
1998 & 0.232 & 0.223 \\
1999 & 0.263 & 0.245 \\
2000 & 0.260 & 0.235 \\
2001 & 0.250 & 0.229 \\
2002 & 0.263 & 0.240 \\
2003 & 0.261 & 0.205 \\
2004 & 0.259 & 0.228 \\
\hline
\end{tabular}


Table 4. Proportion of Old Age Pensioners Falling Under 50 Percent of Median of Equivalent Disposable Income. 1980 and 1991-2004.

\begin{tabular}{lccc}
\hline & $65-74$ Years & 75 Years and Older & All Old Age pensioners \\
\hline 1980 & 0.6 & 0.0 & 0.4 \\
1991 & 2.2 & 2.3 & 2.2 \\
1992 & 1.2 & 1.7 & 1.4 \\
1993 & 0.9 & 0.1 & 0.5 \\
1994 & 1.0 & 1.1 & 1.0 \\
1995 & 0.8 & 1.1 & 0.9 \\
1996 & 0.5 & 0.7 & 0.6 \\
1997 & 1.0 & 0.8 & 0.9 \\
1998 & 1.3 & 1.1 & 1.2 \\
1999 & 1.6 & 1.8 & 1.7 \\
2000 & 1.6 & 3.0 & 2.3 \\
2001 & 2.0 & 3.7 & 2.2 \\
2002 & 2.0 & 3.5 & 2.7 \\
2003 & 1.8 & 2.4 & 2.1 \\
2004 & 1.2 & 2.9 & 2.0 \\
Difference 1995/1991 & & & -1.3 \\
Difference 2004/1995 & -1.4 & -1.2 & 1.1 \\
Difference 2004/1991 & 0.4 & 1.8 & -0.2 \\
Difference 2004/1980 & -1.0 & 0.6 & 1.7 \\
\hline
\end{tabular}


Table 5. Proportion of Old Age Pensioners Under 75, 100 and 125 Percent of Swedish National Board of Health and Welfare's Poverty Line. 1980 and 1991-2004.

\begin{tabular}{|c|c|c|c|c|c|c|c|c|c|}
\hline & \multicolumn{3}{|c|}{ 65-74 Years } & \multicolumn{3}{|c|}{75 Years and Older } & \multicolumn{3}{|c|}{$\begin{array}{c}\text { All Old Age } \\
\text { Pensioners }\end{array}$} \\
\hline & $<0.75$ & $<1.00$ & $<1.25$ & $<0.75$ & $<1.00$ & $<1.25$ & $<0.75$ & $<1.00$ & $<1.25$ \\
\hline 1980 & 0.5 & 3.1 & 20.1 & 0.0 & 14.6 & 53.9 & 0.3 & 7.5 & 33.0 \\
\hline 1991 & 0.7 & 2.7 & 8.8 & 0.7 & 7.2 & 31.1 & 0.7 & 4.7 & 18.8 \\
\hline 1992 & 0.5 & 2.7 & 7.8 & 0.7 & 5.8 & 27.7 & 0.6 & 4.0 & 16.3 \\
\hline 1993 & 0.5 & 3.0 & 9.7 & 0.0 & 4.1 & 25.9 & 0.3 & 3.5 & 17.1 \\
\hline 1994 & 0.6 & 2.5 & 10.1 & 0.7 & 5.5 & 29.2 & 0.6 & 3.8 & 18.6 \\
\hline 1995 & 0.7 & 3.4 & 12.3 & 1.0 & 6.7 & 30.9 & 0.8 & 4.9 & 20.7 \\
\hline 1996 & 0.4 & 3.0 & 12.6 & 0.5 & 6.5 & 30.4 & 0.4 & 4.7 & 21.2 \\
\hline 1997 & 0.6 & 3.7 & 14.0 & 0.7 & 8.5 & 35.1 & 0.6 & 6.1 & 24.4 \\
\hline 1998 & 0.8 & 3.7 & 14.7 & 0.7 & 11.6 & 37.0 & 0.7 & 7.7 & 25.9 \\
\hline 1999 & 1.3 & 3.8 & 11.2 & 1.1 & 7.3 & 29.0 & 1.2 & 5.6 & 20.2 \\
\hline 2000 & 1.1 & 3.3 & 11.7 & 0.9 & 7.9 & 28.7 & 1.0 & 5.7 & 20.5 \\
\hline 2001 & 0.7 & 3.5 & 11.2 & 0.9 & 6.5 & 25.9 & 0.7 & 3.8 & 12.6 \\
\hline 2002 & 0.8 & 2.5 & 8.4 & 0.7 & 4.5 & 19.4 & 0.7 & 3.5 & 14.0 \\
\hline 2003 & 0.9 & 2.6 & 7.3 & 0.5 & 3.7 & 16.8 & 0.7 & 3.2 & 12.1 \\
\hline 2004 & 0.5 & 1.7 & 6.3 & 0.6 & 4.1 & 15.0 & 0.5 & 2.9 & 10.5 \\
\hline Difference 1995/1991 & 0.0 & 0.7 & 3.5 & 0.3 & -0.5 & -0.2 & 0.1 & 0.2 & 1.9 \\
\hline Difference 2004/1995 & -0.2 & -1.7 & -6.0 & -0.4 & -2.6 & -15.9 & -0.3 & -2.0 & -10.2 \\
\hline Difference 2004/1991 & -0.2 & -1.0 & -2.5 & -0.1 & -3.1 & -16.1 & -0.2 & -1.9 & -8.3 \\
\hline Difference 2004/1980 & 0.0 & -1.4 & -13.8 & 0.6 & -10.5 & -38.9 & 0.2 & -4.6 & -22.5 \\
\hline
\end{tabular}


Table 6. Decomposition of Equivalent Disposable Income (EDI) by Source in Families with Householdhead 65 Years or Older. 1975,1991 and 2004.

\begin{tabular}{|c|c|c|c|c|c|c|c|c|c|c|c|c|}
\hline & \multicolumn{4}{|c|}{1975} & \multicolumn{4}{|c|}{1991} & \multicolumn{4}{|c|}{2004} \\
\hline & $\begin{array}{l}\text { Ratio to } \\
\text { social } \\
\text { assistance } \\
\text { norm with } \\
\text { housing }\end{array}$ & $\begin{array}{l}\text { Percent of } \\
\text { EDI }\end{array}$ & $\begin{array}{l}\text { Gini- and } \\
\text { Concen- } \\
\text { tration- } \\
\text { coeffici- } \\
\text { ents }\end{array}$ & $\begin{array}{l}\text { Contri- } \\
\text { bution to } \\
\text { Gini- } \\
\text { coefficient }\end{array}$ & $\begin{array}{l}\text { Ratio to } \\
\text { social } \\
\text { assistance } \\
\text { norm with } \\
\text { housing }\end{array}$ & $\begin{array}{l}\text { Percent of } \\
\text { EDI }\end{array}$ & $\begin{array}{l}\text { Gini- and } \\
\text { Concen- } \\
\text { tration- } \\
\text { coeffici- } \\
\text { ents }\end{array}$ & $\begin{array}{l}\text { Contri- } \\
\text { bution to } \\
\text { Gini- } \\
\text { coefficient }\end{array}$ & $\begin{array}{l}\text { Ratio to } \\
\text { social } \\
\text { assistance } \\
\text { norm with } \\
\text { housing }\end{array}$ & $\begin{array}{l}\text { Percent of } \\
\text { EDI }\end{array}$ & $\begin{array}{l}\text { Gini- and } \\
\text { Concen- } \\
\text { tration- } \\
\text { coeffici- } \\
\text { ents }\end{array}$ & $\begin{array}{l}\text { Contri- } \\
\text { bution to } \\
\text { Gini- } \\
\text { coefficient }\end{array}$ \\
\hline Factor income & 0.412 & 34.2 & 0.558 & 0.191 & 0.483 & 26.9 & 0.568 & 0.153 & 0.592 & 28.2 & 0.730 & 0.206 \\
\hline Earnings of men & 0.176 & 14.6 & 0.680 & 0.099 & 0.077 & 4.3 & 0.831 & 0.035 & 0.088 & 4.2 & 0.857 & 0.036 \\
\hline Earnings of women & 0.073 & 6.0 & 0.730 & 0.044 & 0.093 & 5.2 & 0.744 & 0.038 & 0.091 & 4.3 & 0.744 & 0.032 \\
\hline Capital income & 0.164 & 13.6 & 0.351 & 0.048 & 0.314 & 17.5 & 0.452 & 0.079 & 0.431 & 19.7 & 0.700 & 0.138 \\
\hline Taxable transfers & 1.037 & 86.1 & 0.194 & 0.167 & 1.822 & 101.5 & 0.211 & 0.214 & 2.257 & 107.6 & 0.191 & 0.205 \\
\hline Pensions & 1.012 & 84.0 & 0.183 & 0.154 & 1.805 & 100.5 & 0.209 & 0.210 & 2.203 & 105.0 & 0.186 & 0.195 \\
\hline Unemployment & 0.005 & 0.4 & 0.452 & 0.002 & 0.002 & 0.1 & 0.505 & 0.001 & 0.008 & 0.4 & 0.538 & 0.002 \\
\hline Others & 0.020 & 1.7 & 0.636 & 0.011 & 0.014 & 0.8 & 0.478 & 0.004 & 0.046 & 2.2 & 0.355 & 0.008 \\
\hline Untaxed transfers & 0.075 & 6.2 & -0.167 & -0.010 & 0.075 & 4.2 & -0.419 & -0.017 & 0.065 & 3.1 & -0.541 & -0.017 \\
\hline General & 0.003 & 0.2 & 0.168 & 0.000 & 0.003 & 0.2 & 0.267 & 0.000 & 0.005 & 0.2 & -0.652 & -0.002 \\
\hline Means tested & 0.072 & 6.0 & -0.181 & -0.011 & 0.072 & 4.0 & -0.448 & -0.018 & 0.060 & 2.8 & -0.531 & -0.015 \\
\hline Total transfers & 1.113 & 92.3 & 0.169 & 0.156 & 1.897 & 105.6 & 0.186 & 0.196 & 2.322 & 110.7 & 0.170 & 0.188 \\
\hline Gross income & 1.525 & 126.5 & 0.274 & 0.347 & 2.380 & 132.5 & 0.264 & 0.350 & 2.914 & 138.9 & 0.284 & 0.394 \\
\hline Taxes & -0.320 & -26.5 & 0.627 & -0.166 & -0.584 & -32.5 & 0.416 & -0.135 & -0.816 & -38.9 & 0.349 & -0.136 \\
\hline EDI & 1.205 & 100.0 & 0.181 & 0.181 & 1.796 & 100.0 & 0.214 & 0.214 & 2.098 & 100.0 & 0.259 & 0.259 \\
\hline Number of persons & 1367831 & & & & 1496537 & & & & 1517719 & & & \\
\hline Number of observations & 1192 & & & & 1948 & & & & 7065 & & & \\
\hline
\end{tabular}


Figure 1. Development of Equilavent Disposable Income Among Old Age Pensioners. Ratio to the Social Assistance Norm with Housing Costs. 1980 - 2004

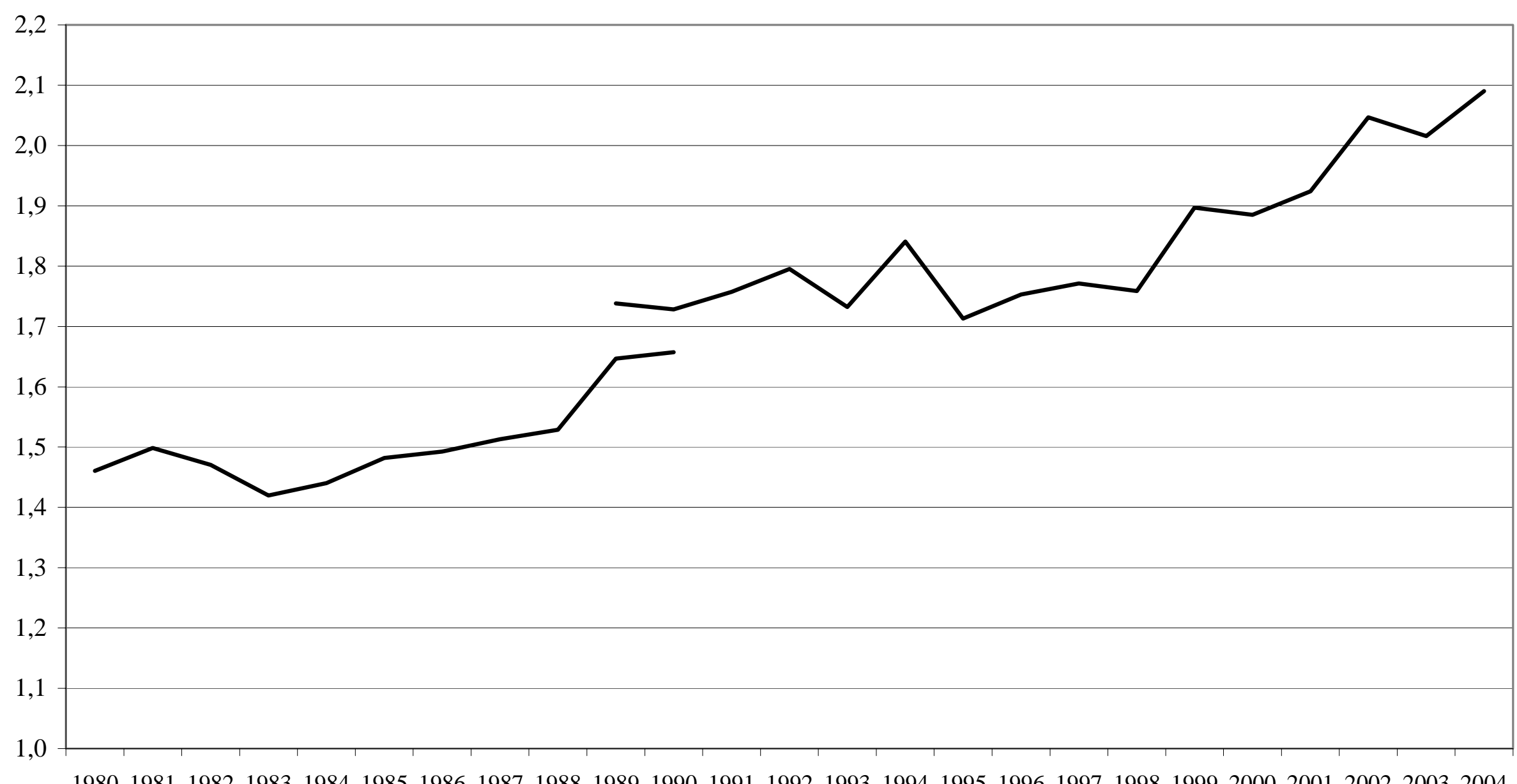


Figure 2a. Quintile Values for equivalent Disposable Income among Pensioners 65-74 Years. Index 1991=100. 1991 - 2004.

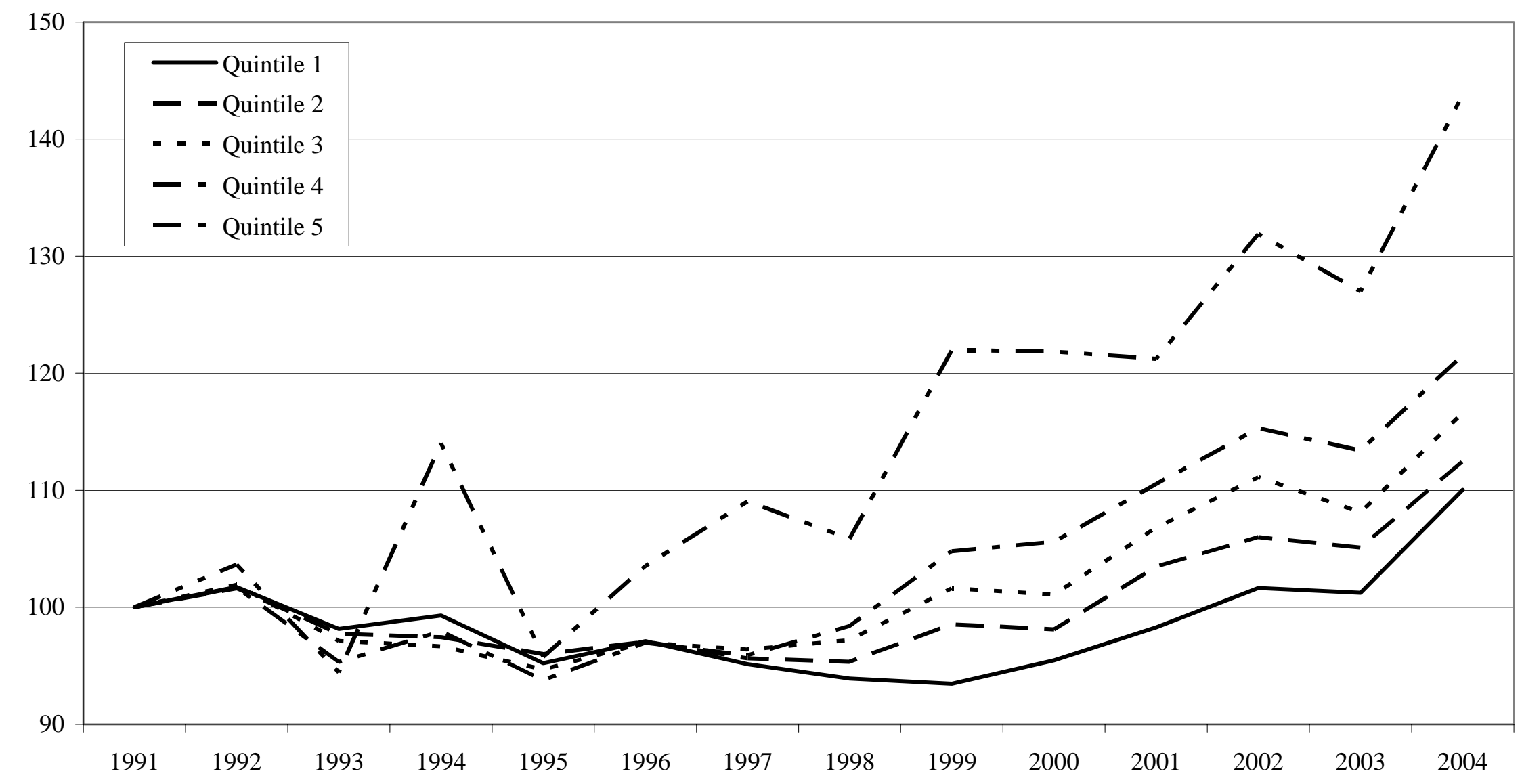


Figure 2b. Quintile Values for Equivalent Disposable Income amomg Pensioners 75 Years and Older. Index 1991=100. 1991 - 2004.

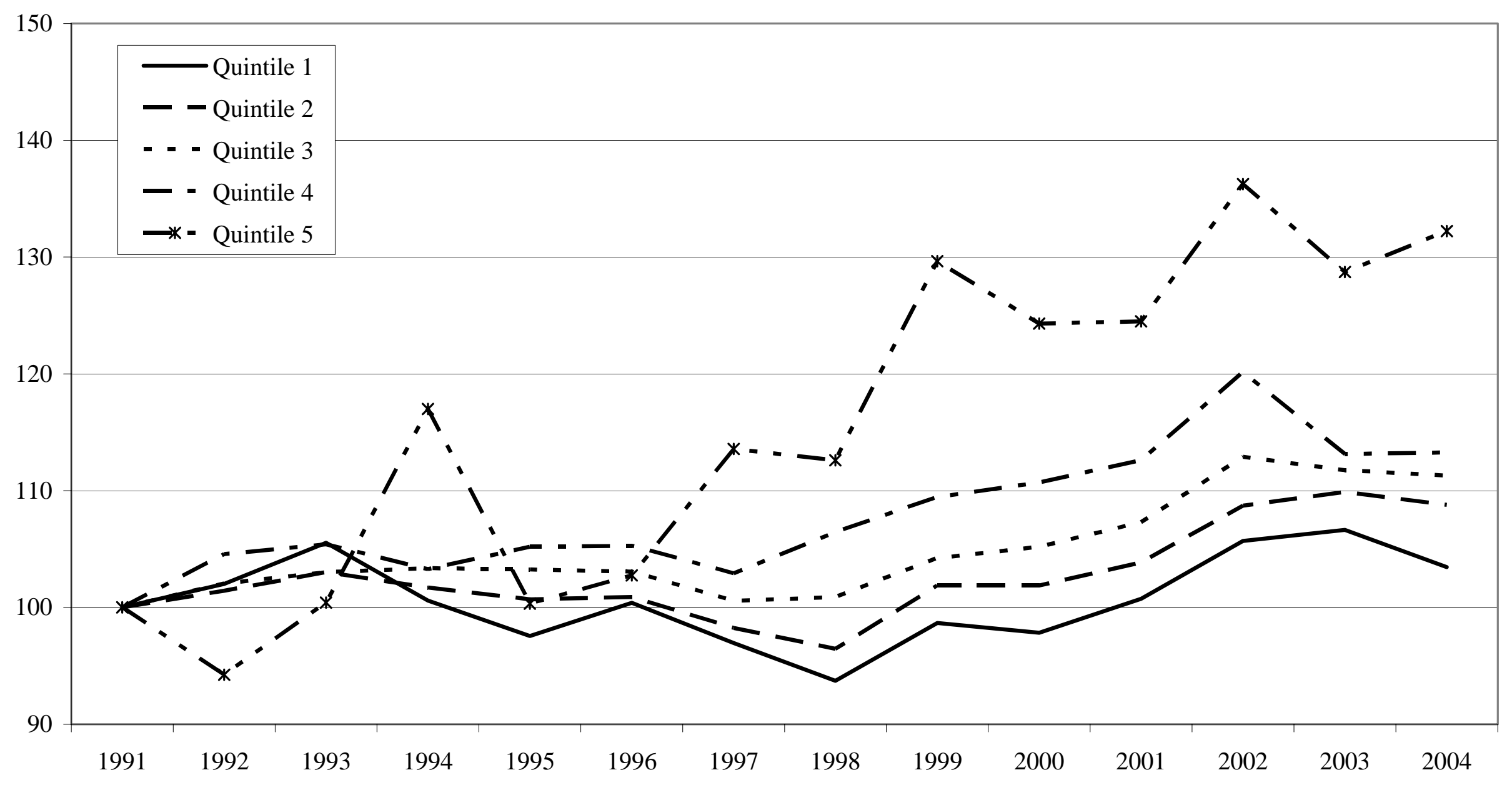


Figure 3a. Proportion of Pensioners age 65 - 74 Years Old Under 75, 100 and 125 Percent of Swedish National Board of Health and Welfare's Poverty Line. 1991 - 2004.

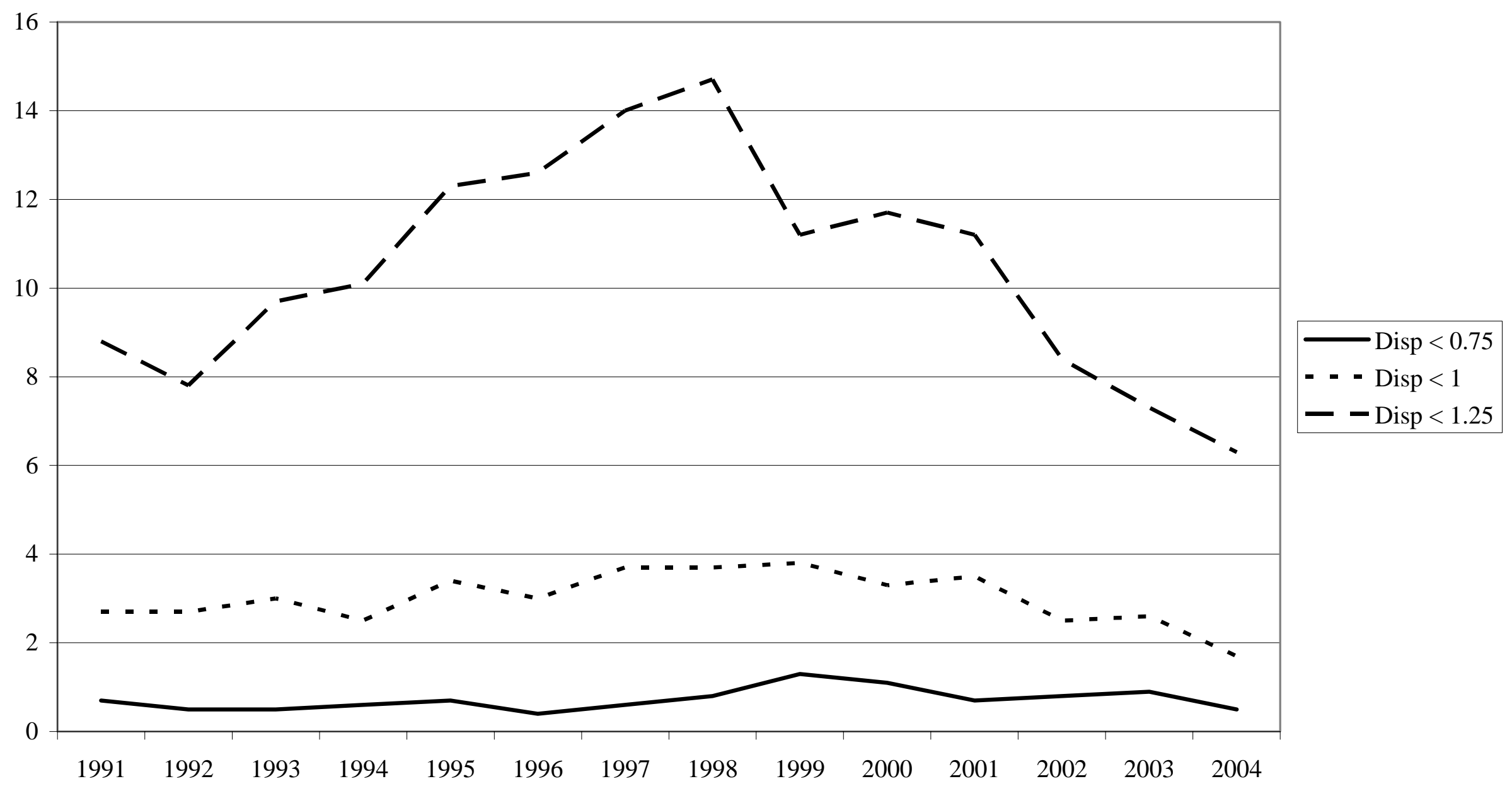


Figure 3b. Proportion of Pensioners 75 Years and Older Under 75, 100 and 125 Percent of Swedish National Board of Health and Welfare's Poverty Line. 1991 - 2004.

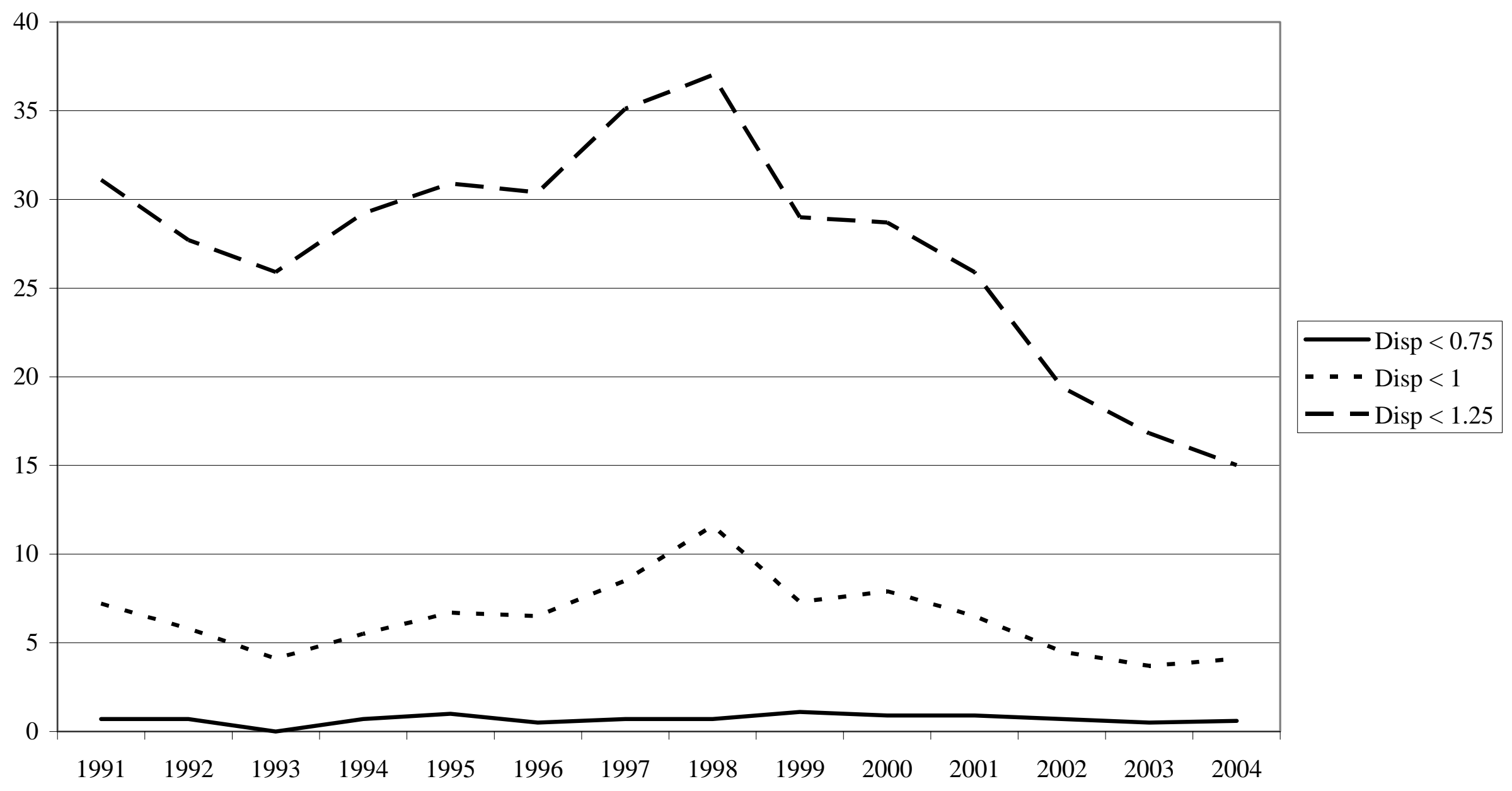


Figure 3c. Proportion of Pensioners Under 75, 100 and 125 Percent of Swedish National Board of Health and Welfare's Poverty Line. 1991 - 2004.

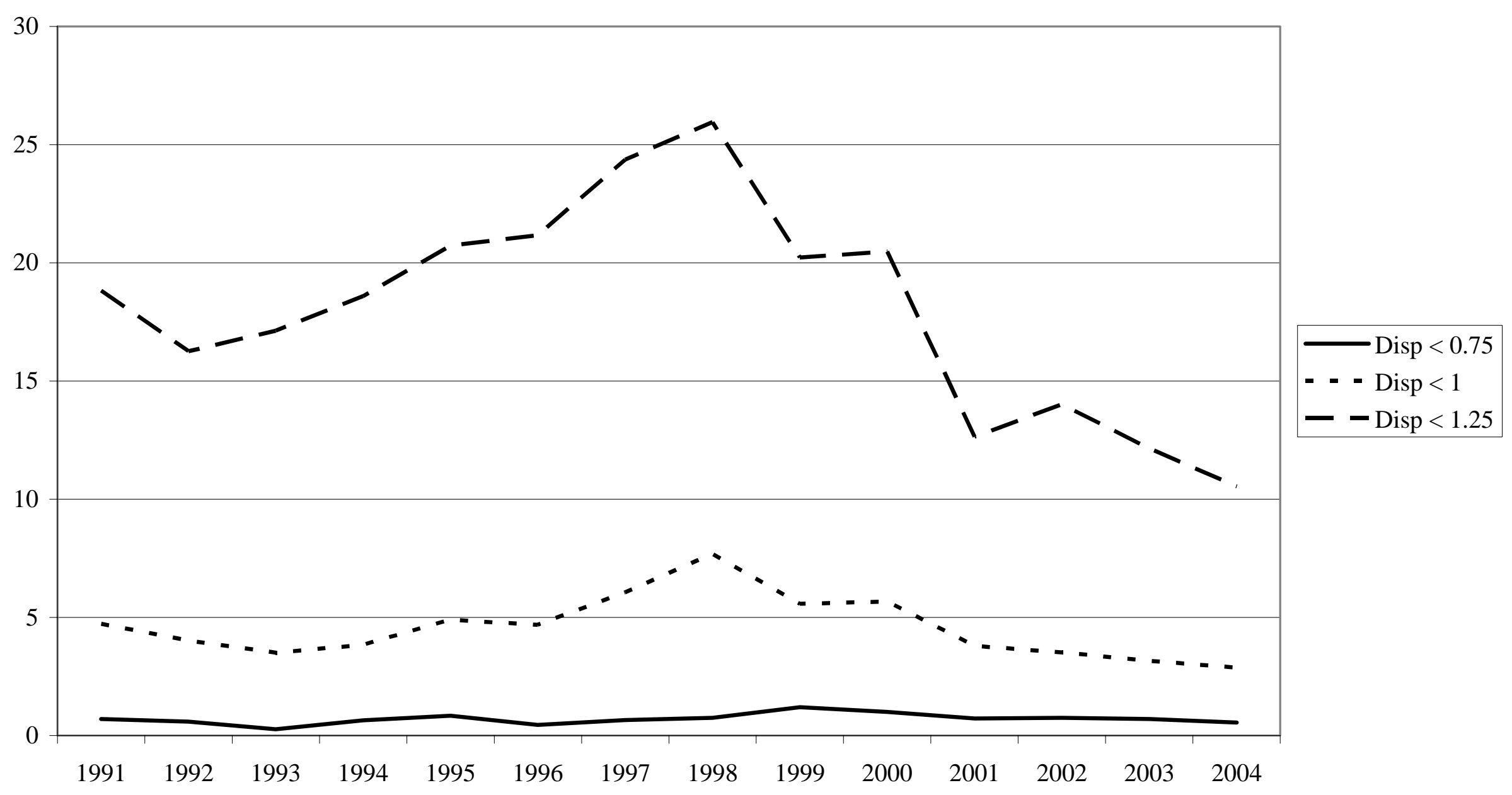


Figure 4. Contributions to Changes in the Gini-coefficient in Families with Household Head aged 65 and Older Since1991. 1991 - 2004.

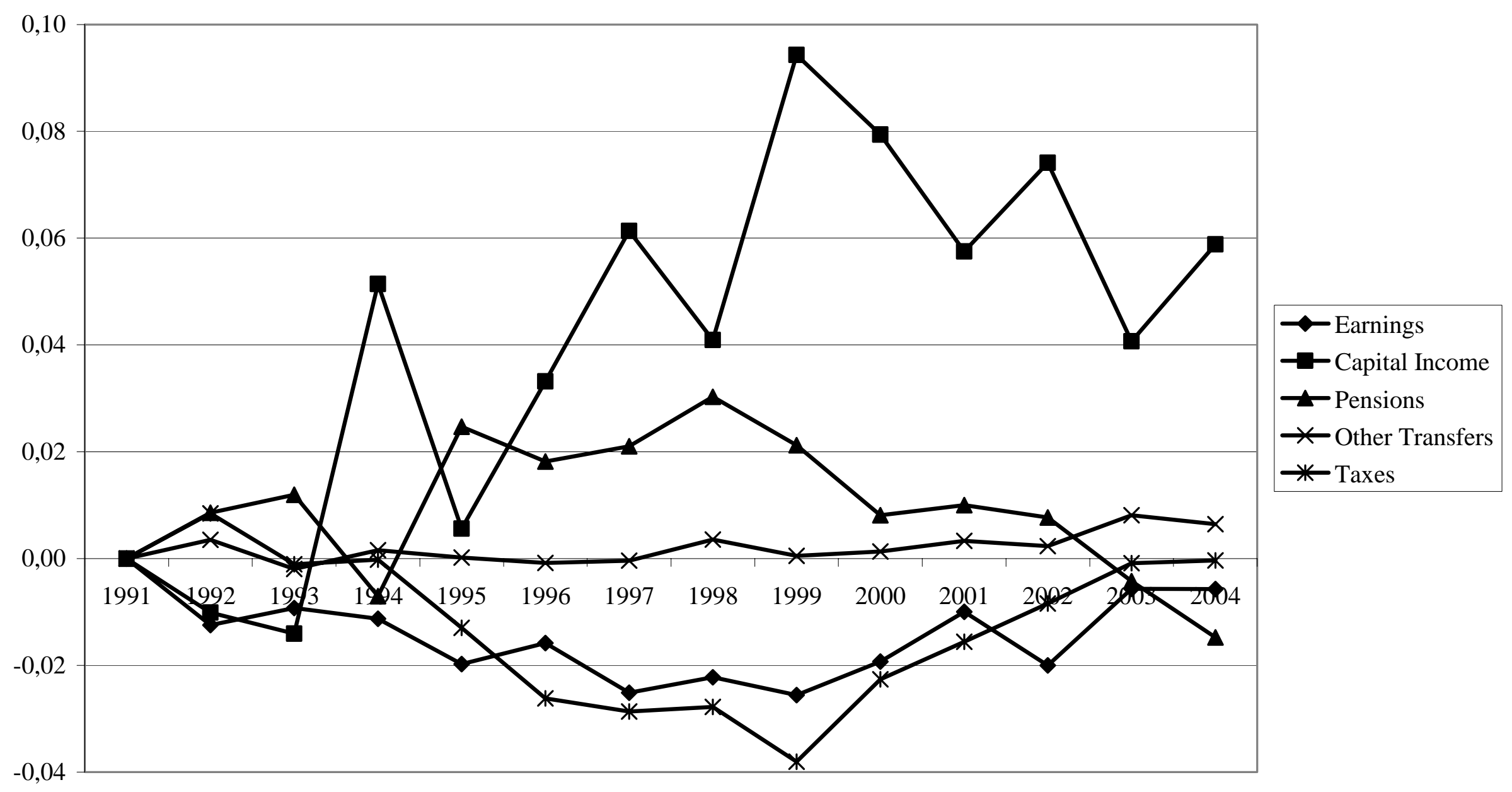

